Dapat diakses pada: http://jkb.ub.ac.id/index.php/jkb/article/view/1288

Jurnal Kedokteran Brawijaya Vol. 29, No. 2, Agustus 2016, pp. 104-109

Online Published First: 8 Agustus 2016

Artikel Penelitian

Article History: Received 4 September 2015, Accepted 10 Desember 2015

\title{
Ekstrak Daging Putih Semangka (Citrulus vulgaris) Menurunkan Kolesterol Total dan Aktivitas Hidroksi-Metilglutaril-KoA Reduktase Tikus Hiperkolesterolemia
}

\section{Watermelon (Citrulus vulgaris) White Pulp Extract Decreases Total Cholesterol and Hydroxy- Methylglutaryl-CoA Reductase Activity in Hypercholesterolemic Rats}

\author{
Fany Lairin $D^{1}$, Diana Lyrawati ${ }^{2}$, Setyawati Soeharto ${ }^{3}$ \\ ${ }^{1}$ Program Magister Ilmu Biomedik Fakultas Kedokteran Universitas Brawijaya Malang \\ ${ }^{2}$ Laboratorium Farmasi Fakultas Kedokteran Universitas Brawijaya Malang \\ ${ }^{3}$ Laboratorium Farmakologi Fakultas Kedokteran Universitas Brawijaya Malang
}

\begin{abstract}
ABSTRAK
Penelitian ini bertujuan untuk mengetahui apakah ekstrak daging putih semangka mempengaruhi profil lipid dan memiliki efek hambatan terhadap HMG-KoA reduktase. Pada penelitian ini digunakan 4 kelompok Rattus norvegicus Wistar jantan dengan diet tinggi kolesterol sebagai model hiperkolesterolemia, yaitu (1) tanpa ekstrak, (2) dengan ekstrak daging putih semangka 250, atau (3) 500mg/kgBb/hari, (4) simvastatin 0,9mg/kgBb/hari, dan 1 kelompok tikus diet normal. Profil lipid dianalisis menggunakan metode Cholesterol Peroxidase-Phenol Quinoneimine (CHOD-PAP), sedangkan aktivitas HMGKoA reduktase dianalisis secara spektrofotometri. Hasil penelitian menunjukkan bahwa pada tikus hiperkolesterolemia ekstrak daging putih semangka ekivalen dengan simvastatin dalam menurunkan kadar kolesterol total ( $p=0,038)$, meningkatkan kadar HDL $(p=0,021)$ dan menghambat aktivitas HMG-KoA reduktase $(p=0,012)$. Hal ini menunjukkan bahwa ekstrak daging putih semangka 250 atau $500 \mathrm{mg} / \mathrm{kgBb} /$ hari dapat dikembangkan sebagai antihiperlipidemia.
\end{abstract}

Kata Kunci: Aktivitas HMG-KoA reduktase, hiperkolesterolemia, profil lipid, semangka

\begin{abstract}
This study aimed to determine whether watermelon white pulp extract could affect lipid profile and inhibit HMG-CoA reductase. In this study, four groups of male Rattus norvegicus fed with high fat diet were used as hypercholesterolemia models, i.e. (1) without extract, (2) with watermelon white pulp extract $250 \mathrm{mg} / \mathrm{kgBW} / \mathrm{d}$, or (3) $500 \mathrm{mg} / \mathrm{kgBW} / \mathrm{d}$, (4) with simvastatin $0,9 \mathrm{mg} / \mathrm{kgBW} / \mathrm{d}$, and 1 group of rats with normal diet. Lipid profiles were analyzed using Cholesterol Peroxidase-Phenol Quinoneimine (CHOD-PAP) method, whereas HMG-CoA reductase activity was determined spectrophotometrically. The results showed that in hypercholesterolemic rats watermelon white pulp extract was equivalent with simvastatin in decreasing total cholesterol ( $p=0,038$ compared to that of high fat diet rats value), increasing HDL level $(p=0,021)$, and inhibiting HMG-CoA reductase $(p=0,012)$. In conclusion, watermelon white pulp extract at 250 or $500 \mathrm{mg} / \mathrm{kgBW} / \mathrm{d}$ could be developed further as antihyperlipidemic agent.
\end{abstract}

Keywords: HMG-CoA reductase activity, hypercholesterolemia, lipid profile, watermelon

Korespondensi: Diana Lyrawati. Laboratorium Farmasi Fakultas Kedokteran Universitas Brawijaya Malang, Jl. Veteran Malang Jawa TimurTel.(0341)569117Email: eldi_7_98@yahoo.com 


\section{PENDAHULUAN}

Peningkatan kadar kolesterol dalam darah mengakibatkan suatu keadaan yang dinamakan hiperkolesterolemia (1). Hiperkolesterolemia diketahui merupakan salah satu faktor penyebab terjadinya penyakit kardiovaskuler antara lain penyakit jantung koroner (PJK), penyebab kematian utama di dunia. Setiap tahun jumlah kematian pada wanita 3,4 juta dan laki-laki 3,8 juta di seluruh dunia akibat penyakit ini (2). Di Indonesia dilaporkan prevalensi hiperkolesterolemia pada tahun 2003-2004 sebesar 15,5\% dan meningkat pada tahun 2008-2009 sebesar 19,4\% (3).

Kolesterol dibentuk melalui asetat yang diproduksi dari nutrien dan energi beserta hasil metabolisme lainnya. Pembentukan kolesterol melalui asetat merupakan proses yang kompleks dan yang berperan penting adalah enzim hidroksi-metilglutaril-KoA reduktase (HMG-KoA reduktase). HMG-KoA reduktase mengubah HMG-KoA menjadi mevalonat yang selanjutnya diubah menjadi kolesterol (4). Ketika HMG-KoA reduktase ini dihambat akan terjadi penurunan sintesis kolesterol di hati (5). Obat sintetis yang sering dikonsumsi oleh masyarakat untuk menurunkan kadar kolesterol adalah golongan statin antara lain simvastatin, namun penggunaan statin dalam jangka panjang dilaporkan memiliki efek samping munculnya miopati dan gagal ginjal (6).

Daging putih buah semangka (Citrulus vulgaris) merupakan bahan alami yang dapat digunakan untuk mengobati berbagai penyakit. Dari hasil penapisan fitokimia diketahui bahwa dalam ekstrak pulpa daging putih semangka terkandung senyawa alkaloid, flavonoid, tannin dan polifenol (7). Maryati et al melaporkan senyawa flavonoid yang ditemukan pada genus Garcinia menghambat sintesis kolesterol melalui hambatan terhadap HMG-CoA reduktase. Walaupun flavonoid tanaman berbeda-beda, namun diduga flavonoid semangka juga dapat berefek pada HMG-CoA reduktase dan dapat digunakan sebagai antihperkolesterolemia. Penelitian ini bertujuan untuk membuktikan efek ekstrak daging putih semangka terhadap profil lipid dan aktivitas HMG-CoA reduktase. Dalam studi ini, metode enzimatik CHOD-PAP (Cholesterol- Oxidase Phenol Aminoantipyrin) digunakan untuk mengukur kadar HDL, LDL dan kolesterol total dan spektrofotometri untuk mengukur aktivitas enzim HMG-CoA reduktase.

\section{METODE}

\section{Desain Penelitian}

Penelitian ini bersifat true experimental post-test only. Dalam penelitian ini digunakan 25 ekor Rattus novergicus Wistar berumur 2-3 bulan, berat badan 150-200gram yang diperoleh dari Laboratorium Farmakologi Universitas Brawijaya Malang. Seluruh tikus dipelihara di Laboratorium Farmakologi Universitas Brawijaya Malang yang ditempatkan dalam kandang yang terbuat dari wadah plastik berukuran $23 \mathrm{~cm}$ x $17 \mathrm{~cm}$ x 9,5cm dengan alas sekam padi dan tutup dari anyaman kawat. Akses makan dan minum ad libitum, namun pakan dibedakan tergantung kelompok perlakuan. Semua perlakuan terhadap hewan coba berdasarkan persetujuan laik etik dari Komisi Etik Penelitian Kesehatan Fakultas Kedokteran Universitas Brawijaya Malang (No: 277/EC/KEPK/04/ 2015).

\section{Perlakuan pada Hewan Percobaan}

Dilakukan pemilihan secara acak setiap kelompok terdiri dari 5 ekor tikus, dengan pengelompokan sebagai berikut (i) normal (K-): kelompok kontrol normal yang diberi pakan standar, (ii) kelompok kontrol positif hiperkolesterolemia $(\mathrm{K}+)$ yaitu tikus yang diberi pakan tinggi kolesterol, (iii) kelompok hiperkolesterolemia yang mendapat ekstrak daging putih semangka dosis $250 \mathrm{mg} / \mathrm{kgBB} /$ hari (KP1), (iv) kelompok hiperkolesterolemia yang mendapat ekstrak daging putih semangka dosis $500 \mathrm{mg} / \mathrm{kgBB} /$ hari, dan (v) kelompok hiperkolesterolemia yang mendapat simvastatin dosis $0,9 \mathrm{mg} / \mathrm{kgBB} /$ hari. Sebelum perlakuan, semua tikus diadaptasikan pada dalam kondisi lingkungan penelitian selama satu minggu. Setelah adaptasi, semua tikus diberi pakan tinggi kolesterol selama 4 minggu kecuali kelompok kontrol normal, kemudian dilanjutkan dengan pemberian ekstrak daging putih semangka dan simvastatin selama 4 minggu. Pada akhir minggu ke delapan, tikus dikorbankan untuk diambil darah dan jaringan hatinya untuk pemeriksaan profil lipid dan HMGKoA reduktase.

Pemeriksaan Profil Lipid Darah (Kadar LDL, Kolesterol Total dan $H D L)$

Pemeriksaan kadar LDL, kolesterol total, dan HDL dilakukan dengan metode CHOD-PAP (CholesterolOxidase Phenol Aminoantipyrin). Larutan blanko, baku dan sampel direaksikan dengan reagen $1,0 \mathrm{~mL}$, kemudian diinkubasi selama 10 menit pada suhu $37^{\circ} \mathrm{C}$. Absorbansi larutan diukur menggunakan spektrofotometer, untuk $\mathrm{HDL}$ pada panjang gelombang $500 \mathrm{~nm}$. Untuk pemeriksaan $\mathrm{LDL}$, digunakan panjang gelombang $585 \mathrm{~nm}$.

\section{Pembuatan Homogenat Jaringan Hati}

Sampel organ hati, $300 \mathrm{mg}$ setiap tikus, dicuci dengan larutan dapar fosfat (PBS) untuk menghilangkan darah yang melekat di organ hati. Hati kemudian dimasukkan ke tabung mikro Eppendorf dan dihaluskan menggunakan micropestle sampai halus. Setelah itu, ditambahkan dengan PBS $1 \mathrm{~mL}$, dihomogenkan dengan Vortex, kemudian disentrifugasi, $3000 \mathrm{rpm}, 7$ menit. Pelet digunakan untuk uji aktivitas HMG-KoA reduktase, supernatan $500 \mu \mathrm{L}$ disimpan pada $-86^{\circ} \mathrm{C}$ hingga siap untuk digunakan.

\section{Uji Aktivitas HMG-CoA Reduktase}

Aktivitas enzim HMG-CoA reduktase diuji secara kolorimetri menggunakan HMG-KoA reduktase Assay Kit (BIOVISION, Cat.\# K588-100). Sebanyak $1 \mu \mathrm{L}$ HMG-CoA reduktase ditambahkan ke pelet jaringan hati selanjutnya dihomogenkan dengan Vortex. Sejumlah $100 \mu \mathrm{L}$ homogenat dimasukkan pada sumuran pelat ELISA. Kemudian dibuat campuran reaksi yang terdiri dari HMGKoA $12 \mu \mathrm{L}$, NADPH $4 \mu \mathrm{L}$, HMG-KoA reduktase Assay Buffer $174 \mu \mathrm{L}$. Sebanyak $100 \mu \mathrm{L}$ campuran reaksi tersebut ditambahkan pada sumuran. Setelah diinkubasi selama 10 menit, dilakukan pengukuran absorbansi menggunakan spektrofotometer pada panjang gelombang $401 \mathrm{~nm}$. Pembacaan dilakukan setiap 2 menit selama 10 menit.

\section{Analisis Statistik}

Efek ekstrak daging putih semangka terhadap kadar LDL, HDL, kolesterol total dan aktivitas HMG-KoA reduktase dianalisis menggunakan One-Way ANOVA dan dilanjutkan dengan uji LSD (SPSS ver. 22). Perbedaan signifikan 
Tabel 1. Berat badan (bb, gram) hewan coba penelitian

\begin{tabular}{|c|c|c|c|c|c|}
\hline \multirow{2}{*}{$\begin{array}{c}\text { Perlakuan } \\
\text { Kontrol normal (diet normal) }\end{array}$} & \multicolumn{2}{|c|}{ Rerata bb Awal \pm SD } & \multicolumn{2}{|c|}{ Rerata bb Akhir \pm SD } & \multirow{2}{*}{$\frac{\text { Rerata Peningkatan bb } \pm \text { SD }}{111,75 \pm 27,86}$} \\
\hline & $134,25 \pm 6,13$ & $\mathrm{a}$ & $246,0 \pm 27,22$ & $\mathrm{a}$ & \\
\hline $\begin{array}{l}\text { Kontrol hiperkolesterolemia } \\
\text { (diet tinggi kolesterol) }\end{array}$ & $139,75 \pm 4,27$ & $\mathrm{ab}$ & $263,5 \pm 19,28$ & a & $123,75 \pm 17,06$ \\
\hline Ekstrak 250 mg/kgBB/h & $136,50 \pm 6,46$ & ab & $256,5 \pm 10,47$ & a & $120,00 \pm 8,83$ \\
\hline Ekstrak 500 mg/kgBB/h & $144,00 \pm 5,48$ & $\mathrm{~b}$ & $267,75 \pm 23,82$ & $\mathrm{ab}$ & $123,75 \pm 21,52$ \\
\hline Simvastatin & $155,75 \pm 3,40$ & c & $295,5 \pm 20,57$ & b & $139,75 \pm 20,35$ \\
\hline
\end{tabular}

Keterangan: Huruf yang berbeda pada rerata \pm SD (simpangan baku) menandakan perbedaan yang bermakna $(p<0,05)$

ditunjukkan dengan nilai $P<0,05$.

\section{HASIL}

\section{Rerata Berat Badan dan Konsumsi Pakan Tikus}

Hasil penelitian menunjukkan terjadinya peningkatan berat badan pada masing masing kelompok perlakuan setiap minggu di mana peningkatan berat badan yang tertinggi terdapat pada kelompok yang diberikan simvastatin+diet tinggi kolesterol. Sedangkan kelompok dengan diet tinggi kolesterol dan pemberian ekstrak daging putih semangka $250 \mathrm{mg} / \mathrm{kgbb} / \mathrm{h}$ merupakan kelompok dengan peningkatan berat badan terendah (Tabel 1). Uji statistik one-way ANOVA menunjukkan tidak ada pengaruh yang signifikan pada pemberian ekstrak daging putih semangka dan simvastatin terhadap peningkatan berat badan $(p=0,649)$.

Rerata konsumsi pakan tertinggi terdapat pada kelompok kontrol negatif dengan pakan standar $(26,62 \pm 6,83 \mathrm{~g})$ dan konsumsi rerata pakan terendah terdapat pada kelompok diet tinggi kolesterol yang diberi ekstrak daging putih semangka dosis $250 \mathrm{mg} / \mathrm{kgbb} / \mathrm{h}$ (Tabel 2). Perbedaan signifikan ditunjukkan pada kelompok yang diberi simvastatin.

Tabel 2. Konsumsi pakan hewan coba

\begin{tabular}{lcc}
\hline \multicolumn{1}{c}{ Perlakuan } & $\begin{array}{c}\text { Konsumsi pakan (gram) } \\
\text { rerata } \pm \text { simpangan baku }\end{array}$ \\
\hline $\mathbf{K}(-)$ & $33,996 \pm 3,082$ & $\mathrm{c}$ \\
$\mathbf{K}(+)$ & $23,921 \pm 2,917$ & $\mathrm{a}$ \\
$\mathbf{2 5 0} \mathbf{~ m g / k g b b / h}$ ekstrak & $23,592 \pm 1,934$ & $\mathrm{a}$ \\
$\mathbf{5 0 0} \mathbf{~ m g / k g b b / h ~ e k s t r a k}$ & $24,504 \pm 3,593$ & ab \\
Simvastatin & $29,304 \pm 4,200$ & $\mathrm{bc}$ \\
nilai-p & 0,001 & \\
\hline
\end{tabular}

Keterangan: Huruf yang berbeda pada rerata \pm SD (simpangan baku) menandakan perbedaan yang bermakna $(p<0,05)$

\section{Pengaruh Ekstrak Daging Putih Semangka terhadap Kadar $L D L$}

Dari hasil penelitian ini didapatkan rerata kadar LDL pada kelompok kontrol diet normal $14 \mathrm{mg} / \mathrm{dL}$ yang sesuai rentang kadar LDL tikus normal (2-27mg/dL). Pemberian ekstrak daging putih semangka dosis $250 \mathrm{mg} / \mathrm{kgBB} / \mathrm{h}$ dan $500 \mathrm{mg} / \mathrm{kgBB} / \mathrm{h}$ menurunkan kadar LDL tikus yang diberi diet tinggi kolesterol dibandingkan dengan kelompok kontrol positif yang hanya diberi diet tinggi kolesterol
(Gambar 1). Secara statistik, tidak terdapat perbedaan kadar LDL yang signifikan antara kelompok kontrol normal dan kelompok yang diberi diet tinggi kolesterol baik dengan maupun tanpa ekstrak daging putih semangka atau simvastatin ( $p=0,185$, One-way ANOVA).

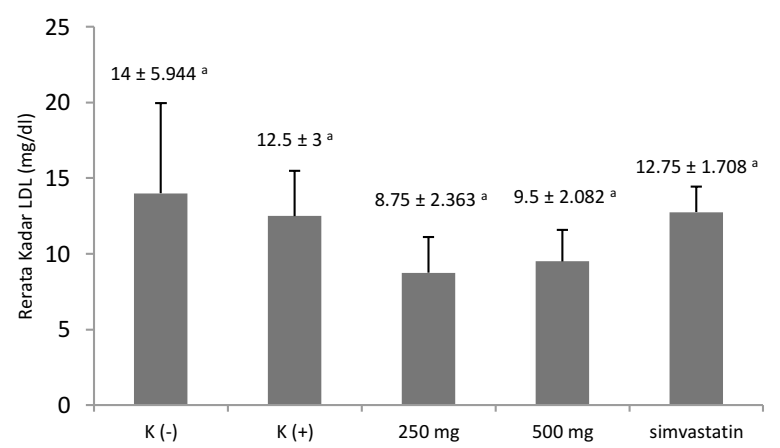

Gambar 1. Perbedaan rerata kadar LDL antar kelompok kontrol dan perlakuan

Keterangan: Notasi huruf $(a, b, c)$ yang berbeda menunjukkan perbedaan yang bermakna $(p<0,05)$ dan jika memuat huruf yang sama berarti tidak ada perbedaan yang bermakna $(p>0,05)$.

Pengaruh Ekstrak Daging Putih Semangka terhadap Kadar $H D L$

Penurunan kadar HDL serum terjadi pada kelompok yang mendapat diet tinggi kolesterol $(48,25 \pm 7,932 \mathrm{mg} / \mathrm{dL})$. Sebaliknya, peningkatan kadar HDL serum terjadi pada kelompok tikus diet tinggi kolesterol yang mendapat ekstrak daging putih semangka $250 \mathrm{mg} / \mathrm{kgbb} / \mathrm{h}$ $(55,5 \pm 12,557 \mathrm{mg} / \mathrm{dL}), 500 \mathrm{mg} / \mathrm{kgbb} / \mathrm{h}(75,5 \pm 20,273 \mathrm{mg} / \mathrm{dL})$ dan kelompok simvastatin $0,9 \mathrm{mg} / \mathrm{kgbb} / \mathrm{h}$ $(89,25 \pm 21,093 \mathrm{mg} / \mathrm{dL})$. Kadar HDL kelompok ekstrak daging putih semangka dosis $250 \mathrm{mg} / \mathrm{kgbb} / \mathrm{h}$ tidak berbeda bermakna dibanding kelompok diet tinggi kolesterol $(p=0,503)$. Kadar HDL kelompok ekstrak daging putih semangka $500 \mathrm{mg} / \mathrm{kgbb} / \mathrm{h}$ lebih tinggi dibandingkan dengan kelompok kontrol diet tinggi kolesterol, $(p=0,021)$, demikian juga kelompok simvastatin $(p=0,001)$. Tidak terdapat perbedaan bermakna antara kadar HDL kelompok ekstrak daging putih semangka dosis $500 \mathrm{mg} / \mathrm{kgbb} / \mathrm{h}$ dengan kelompok simvastatin $(p=0,212)$. Hal ini membuktikan bahwa pemberian ekstrak daging putih semangka dengan dosis $500 \mathrm{mg} / \mathrm{kgbb} / \mathrm{h}$ memiliki potensi yang sama dengan simvastatin dalam meningkatkan HDL. 
Pengaruh Ekstrak Daging Putih Semangka terhadap Kadar Kolesterol Total

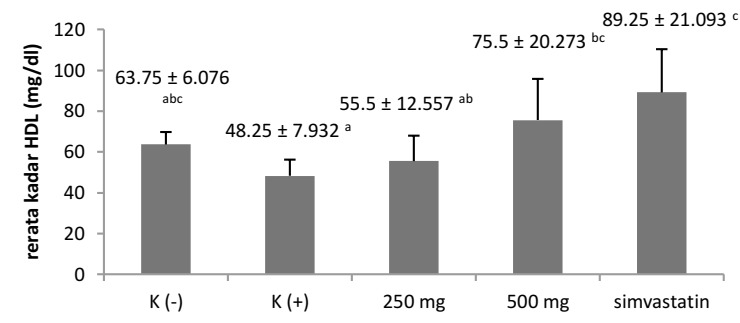

Gambar 2. Perbedaan kadar HDL antar kelompok kontrol dan perlakuan

Keterangan: Notasi huruf $(a, b, c)$ yang berbeda menunjukkan perbedaan yang bermakna $(p<0,05)$ dan jika memuat huruf yang sama berarti tidak ada perbedaan yang bermakna $(p>0,05)$

Pada kelompok kontrol diet tinggi kolesterol kadar kolesterol total mengalami peningkatan bermakna $(108,0 \pm 27,41 \mathrm{mg} / \mathrm{dL})$, lebih tinggi dari kelompok kontrol diet normal $(67,25 \pm 8,617 \mathrm{mg} / \mathrm{dL})$ (Gambar 3). Terjadi penurunan kadar kolesterol total pada kelompok perlakuan yang diberikan ekstrak daging putih semangka $(p=0,038)$. Kadar kolesterol total kelompok kontrol positif berbeda bermakna dengan kelompok ekstrak daging putih semangka dosis $250 \mathrm{mg} / \mathrm{kgBB}(\mathrm{p}=0,004)$, kelompok kontrol positif dengan kelompok dosis $500 \mathrm{mg} / \mathrm{kgbb}$ $(p=0,018)$. Tidak ada perbedaan signifikan pada kadar kolesterol total antara kelompok normal, dan kelompok diet tinggi kolesterol yang mendapat ekstrak daging putih semangka atau simvastatin. Pemberian ekstrak daging putih semangka memiliki potensi yang sama dengan simvastatin dalam menurunkan dan menormalkan kadar kolesterol total $(p>0,05)$.

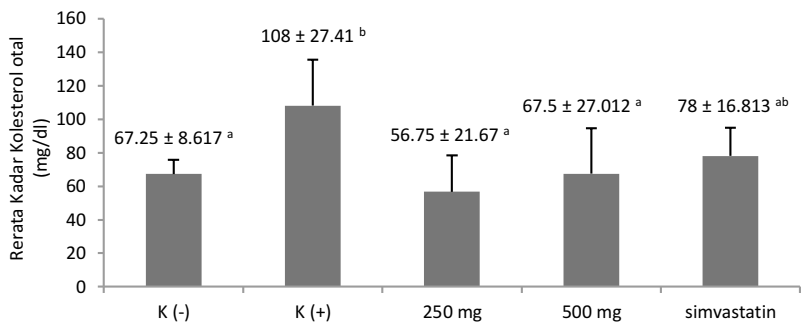

Gambar 3. Perbedaan kadar kolesterol total antar kelompok kontrol dan perlakuan

Keterangan: Notasi huruf $(a, b, c)$ yang berbeda menunjukkan perbedaan yang bermakna $(p<0,05)$ dan jika memuat huruf yang sama berarti tidak ada perbedaan yang bermakna $(p>0,05)$

\section{Pengaruh Ekstrak Daging Putih Semangka terhadap Aktivitas Enzim HMG-Koa Reduktase}

Penurunan aktivitas enzim HMG-KoA reduktase terjadi pada kelompok yang diberikan ekstrak daging putih semangka dan kelompok simvastatin (Gambar 4) yang secara statistik bermakna ( $p=0,012)$. Peningkatan aktivitas HMG-KoA reduktase terjadi pada kelompok kontrol diet tinggi lemak dibandingkan dengan kelompok perlakuan lainnya. Hasil uji statistik menunjukkan perbedaan yang signifikan antara kelompok kontrol positif dengan kelompok ekstrak daging putih semangka dosis $250 \mathrm{mg} / \mathrm{kgbb} / \mathrm{h}, 500 \mathrm{mg} / \mathrm{kgbb} / \mathrm{h}$ dan kelompok simvastatin $0,9 \mathrm{mg} / \mathrm{kgbb} / \mathrm{h}$ (nilai $\mathrm{p}$ masing-masing: $\mathrm{p}=0,002, \mathrm{p}=0,004$, dan $p=0,021)$. Pemberian ekstrak daging putih semangka dengan dosis $250 \mathrm{mg} / \mathrm{kgbb} / \mathrm{h}$ dan $500 \mathrm{mg} / \mathrm{kgbb} / \mathrm{h}$ memiliki potensi yang sama dengan simvastatin dalam menurunkan aktivitas enzim HMG-KoA Reduktase $(p>0,05)$.

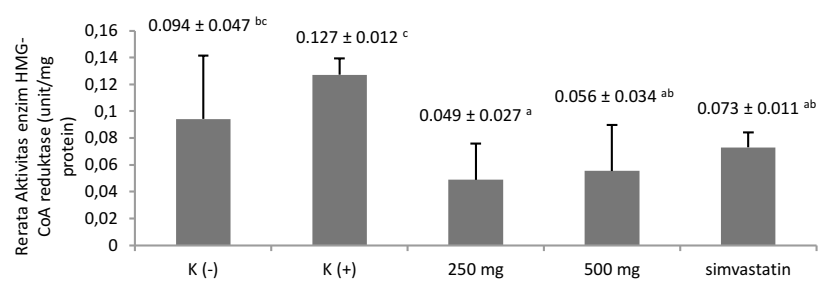

Gambar 4. Perbedaan Aktivitas HMG-KoA reduktase antar kelompok kontrol dan perlakuan

Keterangan: Notasi huruf $(a, b, c)$ yang berbeda menunjukkan perbedaan yang bermakna $(p<0,05)$ dan jika memuat huruf yang sama berarti tidak ada perbedaan yang bermakna $(p>0,05)$

\section{DISKUSI}

Penelitian ini bertujuan untuk membuktikan efek ekstrak daging putih semangka terhadap profil lipid dan aktivitas enzim HMG-KoA reduktase pada Rattus norvegicus galur Wistar model hiperkolesterolemia. Untuk membuat tikus model hiperkolesterolemia, hewan coba diberi diet tinggi kolesterol yang terdiri dari PARS 57,3\%, terigu 31,8\%, kolesterol $1,9 \%$, asam kolat $0,1 \%$, minyak babi $8,9 \%$ selama 8 minggu. Ekstrak daging putih semangka diberikan pada minggu ke 5-8. Penentuan dosis ekstrak yang diberikan didasarkan pada penelitian yang dilakukan oleh Sugiyanta (9) yang menunjukkan dosis $250 \mathrm{mg} / \mathrm{kgBB}$ dan 500mg/kgBB ekstrak daging putih semangka dapat menurunkan kadar glukosa darah tikus model Diabetes Melitus.

Selama perlakuan dilakukan penimbangan berat badan dengan frekuensi sekali dalam seminggu. Berdasarkan hasil perhitungan rerata peningkatan berat badan yang tertinggi terdapat pada kelompok tikus yang diberi diet tinggi kolesterol dan simvastatin. Viviandhari juga menemukan peningkatan berat badan tertinggi pada kelompok tikus yang diberi diet tinggi kolesterol+Simvastatin $0,9 \mathrm{mg} / \mathrm{kgbb}$ dibandingkan dengan kelompok yang diberi ekstrak semangka dan kelompok kontrol diet tinggi lemak saja (10).

Pemberian pakan tinggi kolesterol bertujuan untuk membuat terjadinya hiperkolesterolemia pada kelompok perlakuan. Rerata jumlah konsumsi pakan tinggi kolesterol pada ketiga kelompok perlakuan menunjukkan kelompok yang diberi simvastatin yang mengkonsumsi pakan lebih banyak dibandingkan kelompok perlakuan dengan pemberian ekstrak daging putih semangka dosis $250 \mathrm{mg} / \mathrm{kgbb}$ dan dosis $500 \mathrm{mg} / \mathrm{kgbb}$. Ekstrak daging putih semangka mungkin dapat lebih menekan napsu makan tikus yang diberi diet tinggi kolesterol dibandingkan dengan simvastatin.

Hasil penelitian ini menunjukkan bahwa walaupun mendapat diet tinggi kolesterol, semua kelompok tidak menunjukkan peningkatan kadar LDL melebihi batas 
normal yaitu $2-27 \mathrm{mg} / \mathrm{dL}$. Berdasarkan hasil uji statistik One-Way ANOVA tidak terdapat perbedaan yang signifikan antar kelompok perlakuan $(p>0,05)$. Namun demikian, terdapat kecenderungan penurunan kadar LDL pada kelompok perlakuan yang diberikan esktrak daging putih semangka dibandingkan dengan kelompok perlakuan lainnya. Penurunan kadar LDL pada tikus yang diberikan ekstrak daging putih semangka kemungkinan disebabkan karena adanya kandungan pektin dalam daging putih semangka. Salah satu peran pektin adalah menurunkan kadar kolesterol dalam darah. Mekanisme kerja dari senyawa aktif ini yaitu mengikat kolesterol yang terdapat pada sistem pencernaan sehingga menyebabkan penurunan jumlah kolesterol dalam darah yang juga akan menurunkan kadar LDL sesuai fungsinya sebagai pengangkut kolesterol ke dalam darah (11). Hasil penelitian ini juga menunjukkan bahwa kadar LDL pada tikus dengan pemberian pakan standar relatif lebih tinggi dibandingkan dengan kelompok kontrol diet tinggi lemak. Hardiningsih \& Nurhidayat menemukan kadar kolesterol pada pakan standar/normal sebesar $8,09 \mathrm{mg} / \mathrm{g}$ di mana selisihnya dengan pakan hiperkolesterolemia sebesar 0,005 gram (12). Oleh karena kelompok kontrol diet normal (K-) mengkonsumsi pakan lebih tinggi setiap harinya dibanding kelompok lain, maka asupan kolesterol total juga tinggi. Hal ini mungkin yang menyebabkan kadar LDL relatif lebih tinggi dari kelompok diet tinggi lemak, walaupun secara statistik perbedaan tidak bermakna.

Pemberian ekstrak daging putih semangka memberikan efek terhadap kadar HDL pada tikus perlakuan $(p<0,05)$. HDL merupakan lipoprotein yang berperan membalikkan transport kolesterol (13). Ketika terjadi peningkatan kolesterol HDL itu berarti memperkecil jumlah kolesterol total (14). Daging putih semangka diketahui juga mengandung niasin. Niasin diketahui memiliki peran dalam meningkatkan kadar HDL. Mekanisme kerja senyawa ini dalam meningkatkan kadar HDL yaitu dengan mengurangi pemecahan ApoA-1 HDL dan meningkatkan biosintesis HDL (15). Peningkatan kadar HDL juga dilaporkan oleh Setyaningrum et al pada tikus model hiperlipidemia yang mendapat kombinasi ekstrak daun salam 90mg/200gbb dan niasin 27mg/200gbb (16).

Hasil penelitian menunjukkan adanya penurunan kadar kolesterol total pada kelompok perlakuan yang diberikan ekstrak daging putih semangka. Kolesterol total merupakan kadar keseluruhan kolesterol yang beredar dalam tubuh manusia. Daging putih semangka juga diketahui mengandung senyawa aktif yaitu flavonoid. Salah satu peran senyawa aktif ini yaitu menurunkan kadar kolesterol total $(17,18)$. Mekanisme kerja flavonoid dalam menurunkan kadar kolesterol salah satunya yaitu dengan menghambat kerja enzim HMG-CoA reduktase. Pada penelitian ini ditunjukkan adanya penurunan aktivitas HMG-KoA reduktase pada tikus yang diberikan ekstrak daging putih semangka atau simvastatin. Hasil uji LSD menunjukkan tidak terdapat perbedaan signifikan

\section{DAFTAR PUSTAKA}

1. Murray RK, Mayes PA, Granner DK, and Rodwell VW. Biokimia Harper. Edisi 25. Jakarta: EGC; 2003; hal. 280-281.

2. World Health Organization. Deaths from Coronary Heart Disease. (Online) 2005 . antara kelompok yang diberi ekstrak daging putih semangka dengan kelompok yang diberi simvastatin. Hal ini berarti ekstrak daging putih semangka memiliki potensi yang sama dengan simvastatin dalam menurunkan aktivitas enzim HMG-KoA reduktase.

Penelitian yang dilakukan oleh Anila \& Vijayalakshmi menemukan efek flavonoid yang terdapat pada tanaman Emblica officinalis menghambat aktivitas enzim HMG-KoA reduktase (19). Mekanisme kerja dari flavonoid dalam menurunkan kadar kolesterol total, LDL dan meningkatkan HDL pada tikus model hiperkolesterolemia yang diberi ekstrak daging putih semangka dapat melalui beberapa jalur antara lain melalui hambatan penyerapan kolesterol, peningkatan ekskresi empedu, dan hambatan terhadap aktivitas HMG-CoA reduktase. Mekanisme penghambatan pembentukan kolesterol oleh flavonoid terjadi pada salah satu sisi yang analog (sama) dengan substrat yaitu HMGKoA yang akan diubah menjadi asam mevalonat dengan bantuan enzim HMG-KoA reduktase sehingga flavonoid dapat berkompetisi dengan HMG-KoA untuk berikatan dengan enzim HMG-KoA reduktase (20). HMG-KoA reduktase dilambangkan sebagai enzim utama, flavonoid sebagai inhibitor kompetitif dan HMG-KoA sebagai substrat. HMG KoA reduktase adalah enzim utama yang mendukung sintesis kolesterol di hati dengan cara berikatan dengan mengubah HMG-KoA menjadi mevalonat. Adanya flavonoid sebagai inhibitor menyebabkan HMG-KoA reduktase lebih cenderung berikatan dengan flavonoid sehingga jumlah dan frekuensi pembentukan asam mevalonat berkurang. Asam mevalonat merupakan senyawa antara untuk biosintesis kolesterol sehingga penghambatan pembentukan asam mevalonat dapat menghambat pembentukan kolesterol. Penghambatan terhadap enzim tersebut mampu menekan sintesis kolesterol di hati sebesar 28,3\% (20).

Dapat disimpulkan ekstrak daging putih semangka mampu menurunkan kadar LDL dan kolesterol total, dan meningkatkan kadar HDL pada keadaan hiperkolesterolemia. Ekstrak daging putih semangka 500 $\mathrm{mg} / \mathrm{kgbb} / \mathrm{h}$ memiliki potensi yang ekivalen dengan simvastatin $0,9 \mathrm{mg} / \mathrm{kgbb} / \mathrm{h}$ dalam menurunkan kadar kolesterol total dan menurunkan aktivitas enzim HMG-KoA reduktase, namun secara statistik tidak menunjukkan perbedaan yang signifikan pada kadar LDL pada semua kelompok perlakuan. Penelitian lebih lanjut perlu dilakukan dengan modifikasi lama/durasi diet tinggi lemak atau komposisi diet untuk memperoleh model dengan kadar LDL serum tinggi sehingga dapat melihat apakah ekstrak daging putih semangka dapat menurunkan kadar LDL.

\section{UCAPAN TERIMA KASIH}

Penulis menyampaikan terima kasih kepada lembaga penelitian Universitas Brawijaya dan Yayasan Husada Mandiri Poso yang telah memberikan dana untuk penelitian ini melalui program Beasiswa Dosen Perguruan Tinggi Swasta.

http://www.who.int/cardiovascular_diseases/en/cvd _atlas_14_deathHD.pdf. [diakses tanggal 19 September 2014$]$.

3. Roth GA, Finn SD, Mokdad AH, Aekplakorn W, Hasegawa T, and Lim SS. High Total Serum Cholesterol, Medication Coverage and Therapeutic 
Control: An Analysis of National Health Examination Survey Data from Eight Countries. Bulletin of the World Health Organization; 2010; 89: 92-101.

4. Tobert JA Lovastatin and Beyond: The History of the HMG-Coa Reductase Inhibitors. Nature Review Drug Discovery. 2003; 2(7): 517-526.

5. Bergstrom JD, Bostedor RG, Rew DJ, Geissler WM, Wright SD, and Chao YS. Hepatic Responses to Inhibition of 3-Hydroxy-3-Methylglutaryl-Coa Reductase: A Comparison of Atorvastatin and Simvastatin. Biochimica et Biophysica Acta-Lipids and Lipid Metabolism. 1998; 1389: 213-221.

6. Grundy SM. The Issue of Statin Safety: Where Do We Stand? Circulation. 2005; 111(23): 3016-3019.

7. Fadilah KN. Penapisan Fitokimia Pulpa Kulit Semangka (Citrullus Lanatus, Thumb) dan Pemanfaatannya Sebagai Minuman Kesehatan. (Online) 2012. http://www.digilib.stikesbth.ac.id/page.php?pg=dokumen\& id=27\&title= penapisan-fitokimia-pulpa-kulit-semangka$\% 28$ citrullus-Ianatus--thumb\%29-danpemanfaatannya-sebagai minuman-kesehatan. [diakses tanggal 30 Oktober 2015].

8. Maryati, Wardoyo ERP, dan Widiyantoro A. Potensi Hipolipidemik Senyawa Flavonoid dari Genus Garcinia Hutan Tropika Kalimantan Barat. (Online) 2009. http://elib.pdii.lipi.go.id/katalog/index.php/ searchkatalog/byld/289836. [diakses tanggal 10 september 2014].

9. Sugiyanta. Pengaruh Pemberian Ekstrak Air Daging Putih Semangka (Citrullus vulgaris Schard) terhadap Glukosa Tikus Putih (Rattus norvegicus) yang Diinduksi Streptozotosin. (Online) 2011. http://library.unej.ac.id/client/en_US/default/searc h/detailnonmodal [diakses tanggal: 20 November 2015].

10. Viviandhari D, Yuliani S, dan Akrom. Pengaruh Pemberian Suspensi Sediaan Jinten Hitam (Nigella sativa L) terhadap Kadar Kolesterol Total Tikus Jantan Wistar yang Diberi Diet Tinggi Lemak. Farmasains. 2013; 2(1): 44-49.

11. Sharma M, Fernandes J, Ahirwar D, and Jain R. Hypoglycemic and Hypolipidimic Activity of Alcoholic Extract of Citrus Aurantium in Normal and AlloxanInduced Diabetic Rats. Pharmacologyonline. 2008; 3: 161-171.

12. Hardiningsi R dan Nurhidayat N. Pengaruh Pemberian
Pakan Hiperkolesterolemia terhadap Bobot Badan Tikus Putih Wistar yang Diberi Bakteri Asam Laktat. Biodiversitas. 2006; 7(2): 127-130.

13. Montoya MT, Porres A, Serrano S, et al. Fatty Acid Saturation of the Diet and Plasma Lipid Concentrations, Lipoprotein Particle Concentrations and Cholesterol Efflux Capacity. The American Journal of Clinical Nutrition. 2002; 75(3): 484-491.

14. Griel AE and Kris-Etherton PM. Beyond Saturated Fat: The Importance of the Dietary Fatty Acid Profile on Cardiovascular Disease. Nutrition Reviews. 2006; 64(5): 257-262.

15. Bays HE, Shah A, Lin J, Sisk CM, Dong Q, and Maccubbin D. Consistency of Extended-release Niacin/Laropiprant Effects on $L p(a)$, ApoB, non-HDL-C, Apo A1, and ApoB/ApoA1 Ratio Across Patient Subgroups. American Journal of Cardiovascular Drugs. 2012; 12(3):197-206.

16. Setyaningrum P, Dewi LVI, dan Nopiyanti V. Efek Kombinasi Ekstrak Etanolik Daun Salam (Eugenia Polyantha Wight) dan Niasin terhadap Penurunan Kadar LDL dan Peningkatan Kadar HDL Pada Tikus Putih Jantan. (On I in e) 2015 . https://www.Academia.Edu/8729100/Efek_Kombina si_Ekstrak_Etanolik_Daun_Salam_Eugenia_Polyanth a_Wight._Dan_Niasin_Terhadap_Penurunan_Kadar_ Ldl_Dan_Peningkatan_Kadar_Hdl_Pada_Tikus_Putih _Jantan. [diakses tanggal 17 Juni 2015].

17. Choi JH, Rho MC, Lee SW, et al. Bavachin and Isobavachalcone, Acyl-Coenzyme a: Cholesterol Acyltransferase Inhibitors from Psoralea corylifolia. Archives of Pharmacal Research. 2008; 31(11): 1419 1423.

18. Koo SI and Noh SK. Green Tea as Inhibitor of the Intestinal Absorption of Lipids: Potential Mechanism for Its Lipid- Lowering Effect. Journal of Nutrition Biochemical. 2007; 18(3): 179-183.

19. Anila $L$ and Vijayalakshmi NR. Flavonoids from Emblica Officinalis an Mangifera Indica-Effectiveness for Dyslipidemia. Journal of Ethnopharmacology. 2002; 79(1): 81-87.

20. Bok SH, Lee SH, Park YB, et al. Plasma and Hepatic Cholesterol and Hepatic Activities of 3-Hydroxy-3Methyl-Glutaryl-Coa Reductase and Acyl Coa: Cholesterol Transferase Are Lower in Rats Fed Citrus Peel Extract or a Mixture of Citrus Bioflavonoids. Journal of Nutrition. 1999; 129(6): 1182-1185. 